\title{
Evaluation of Technical and Commercial Losses on Power Distribution Networks in Nigeria Using Statistical Analytical Method
}

\author{
Magnus Iheukwumere Uchechukwu', Okafor N. C. Ephraim² \\ ${ }^{1}$ Electrical/Electronic Engineering, University of Port Harcourt, Port Harcourt, Nigeria \\ ${ }^{2}$ Electrical/Electronic Engineering, Federal University of Technology Owerri, Owerri, Nigeria
}

Email address:

magnusuchechukwu26@gmail.com (M. I. Uchechukwu)

To cite this article:

Magnus Iheukwumere Uchechukwu, Okafor N. C. Ephraim. Evaluation of Technical and Commercial Losses on Power Distribution Networks in Nigeria Using Statistical Analytical Method. American Journal of Electrical and Computer Engineering.

Vol. 5, No. 2, 2021, pp. 56-71. doi: 10.11648/j.ajece.20210502.13

Received: May 16, 2021; Accepted: July 21, 2021; Published: August 31, 2021

\begin{abstract}
Losses are always present in every power distribution system from the source of supply to the point of utilization. The Nigerian electricity industry experiences so many challenges which contribute to the poor electric power supply to the citizens and many losses to the industry. The purpose of this dissertation work is to evaluate technical and commercial losses on power distribution networks in Nigeria using Statistical Analytical Method with Microsoft excel. The procedures followed in order to achieve the purpose of this work centered on the history of power sectors (Generation, Transmission and Distribution) in Nigeria, the theoretical review and the review of previous work done on the topic and different methods used to achieve the results. This work also centered on the data collected from a power distribution industry and its presentation, distribution loss equations and percentage distribution losses, calculations made on the $11 \mathrm{kV}$ distribution feeders and its billing efficiency. Monthly technical and commercial revenue losses and its net revenue losses for a period of one year were achieved. The percentage distribution losses and a chart of distribution losses against the supplied energy on the feeder were also achieved in this work with the challenges encountered. At the end of the work, summary of findings and conclusions were drawn with better contributions and recommendations to improve power industries in Nigeria.
\end{abstract}

Keywords: Generation Company of Nigeria, Transmission Company of Nigeria, Distribution Company of Nigeria, Technical and Commercial Losses, Energy Supplied, Energy Billed, Distribution Losses, Billing Efficiency

\section{Introduction}

\subsection{Background of the Study}

Electric power growth in Nigeria started in the year 1896 when the earliest electricity producing plant was set up in Lagos state. From then until 1929, the Nigeria Electric Supply Company (NESCO) was created as the first power utility company. After twenty-two years (22yrs), the Electric Corporation of Nigeria (ECN) was formed to inherit the assets of Nigeria Electric Supply Company and thereby took the responsibility to generate and distribute electric power to the entire nation. On carrying out the functions, the ECN believed that the electric power supply would on a very good day be available to the whole Nigerians because more power stations were being constructed [18]. In 1962, Nigeria Dam
Authority was also formed to create hydropower potential in the country. After a decade, there was an amalgamation of the Electric Corporation of Nigeria (ECN) and Nigeria Dam Authority (NDA) to form National Electric Power Authority (NEPA) which later changed to Power Holding Company of Nigeria (PHCN) in 2003. The Power Holding Company of Nigeria (PHCN) existed for ten years (10yrs) and later resulted to the unbundling and privatization process of the field of economy (sector) in 2013 [25]. At the earlier time, the Federal Ministry of Power checkmates the electricity industries, served as the regulator, decision making group or organ and direct electric power sectors (electricity industries) in Nigeria via a subdivision in the ministry named Electrical Inspectorate Services (EIS) in [25]. The major challenges within the electricity industry in Nigeria basically involve power outages, unreliable service and losses. These problems 
of power sector have caused the federal government of Nigeria to take thorough actions and enacted the Electric Power Sector Reform Act of 2005 that led to unbundling and privatization process in 2003 which was carried out by the Bureau of Public Enterprises in Nigeria [21]. As a result of these steady power challenges in Nigeria by the late 1990s, during the regime of President Olusegun Obasanjo in 2003, the federal government via National Council on Privatization, NCP and Bureau of Public Enterprises, BPE made much effort to reform the sector due to losses, high electricity demand and no investment. In 2005, Nigeria Electricity Regulatory Commission (NERC) was created via Electric Power Sector Reform Act and then inaugurated in October, 2007 to regulate remote systems, electricity industries in Nigeria, subsidize electricity tariff, and find out the financial percentage to be sent to the rural electrification fund [25].

In August 2010, Power Sector Reform Act was created by the then President Goodluck Ebele Jonathan to handover the federal and state power utilities to the private sector [5]. During the unbundling process of the electricity industry in the late 2013, there was a very high expectations from the masses (Nigerians) that the new owners of the privatized part would quickly put a stop to the frequent power outages, and reduce technical and non-technical (commercial) losses. Currently, the overall power production capacity is about $6427 \mathrm{MW}$ which remain totally inadequate [5].

The unbundling process and privatization of the electricity sector in 2013 led to the existence of six (6) Generation Companies of Nigeria (GENCOs), one Transmission Company of Nigeria (TCN) and eleven (11) Distribution Companies of Nigeria (DISCOs). The Generation Company of Nigeria and the Distribution Company of Nigeria are privatized while the assets of the high voltage $(330 \mathrm{kV} /$ $132 \mathrm{kV})$ transporters (Transmission Company of Nigeria) are still in the possession of the federal government. Losses in electric power network are mainly wasteful energy that happened due to electric energy dissipated in transmission and distribution lines, measurement systems, and power (larger MVA rated/capacity) and distribution ( $k V A$ rated) transformers because of internal electrical resistance or external factors. The national power distribution system have the largest interconnected networks and losses always occur in the system irrespective of the pattern the power system networks are carefully designed. In any electric power distribution system design, considerations on the level of losses have to be taken before the implementation of such design to serve its purpose. Reduction of losses in power distribution system is very important in all human effort and contributions because it leads to greater economic operation of the system. One of the major issues about power loss is to know the quantities of load and how it occurs in other to provide steps to control and reduce it. As a result of this remedy to the electric power losses, effective and very high method of the network operation will be achieved. Electric power supply is very paramount since investment and development demands increase in electric power supply. Secondly, most of the generators, substations, plantdistribution, controls, and sub-transmission equipment used for electric power services are subjected to aging, wear and tear [27]. Inadequate care, maintenance or replacement of all these important equipment as its efficiency frequently dropped cause the system to fail and leads to losses in the nearest feature which in-turn affect the economy of the country.

\subsection{Statement of the Problem}

Losses are always present in every power distribution system from the point of supply (source) to its point of utilization. Power distribution losses are the different between the quantity of energy supplied or delivered to the distribution section from the transmission sector and the quantity of energy received at the customer's end that are billed (technical). It can as well state as the revenue lost by selling non-recorded amount of energy utilized by the customers (non-technical). That is, lost revenue equals to the bulk quantity of energy purchased minus retailed quantity of energy sold to the customer.

If the degrees of these non-technical losses are not controlled, it would result to financial challenges to power utilities. Recent research has shown that, electricity theft which contributes much on non-technical losses account for $30 \%$ to $40 \%$ of the net yearly revenue accrued in Nigeria [4]

The Nigerian electric power industry is faced with unique or particular characteristics such as high technical and nontechnical losses. These occur as a result of undersized cables and conductors used in conveying electricity to the consumers, undersized transformer fuse ratings, poor relay co-ordination when fault happen in the system resulting to non-tripping of circuit breakers.

\subsection{Aim and Objective of the Study}

The aim of this work is to evaluate technical and commercial losses on power distribution networks in Nigeria using Statistical Analytical Method. The objectives of study are;

1) To determine the amount of power purchased and sold, and the amount of power loss.

2) Collection of data on technical and commercial losses from Port Harcourt Electricity Distribution Company.

3) Evaluate the data collected on technical and commercial losses from the Port Harcourt Electricity distribution company as a case study.

\subsection{Significance of Study}

1) To optimize the distribution system and recover a considerable amount of revenue almost equivalent to allocated energy.

2) It will reduce the level at which some customers connive with the staff (mainly marketers and linesmen) to cheat the distribution company by collecting money illegally from the customers and preventing them from paying their electricity bills, by-passing prepaid meters, and shunting of meters to read very slowly by metering personnel. 
3) To minimize the amount of revenue which the power distribution companies lose due to losses incurred from the distribution feeders (networks).

4) Reduce technical losses which will prevent the network from frequent or constant tripping.

5) It will make paying customers have value for their money because they experience high bills when there are many losses.

6) Enactment of useful power sector reform act to help manage the distribution networks.

\subsection{Scope of the Study}

The scope of this work covers

1) The losses incurred due to low voltage distribution lines within Port Harcourt distribution system starting from Akani injection substation to the end of six $11 \mathrm{kV}$ feeders radiated from it.

2) Mathematical and analytical computation of collated data so as to know, estimate and evaluate technical and commercial losses effectively.

3) The work will be limited to determine the overall technical and commercial losses on $11 \mathrm{kV}$ power distribution network and then covert them into monetary terms.

\section{Literature Review}

Power industries in the country have experienced a lot of challenges which have given the Nigerian government and the private investors' concern on how to resolve the issue of daily blackout and losses for over decades. To resolve these inadequate power supply, one should consider how much energy is produced, transported and distributed at the consumer end monthly. Electricity distribution networks (feeders) in Nigeria are designed and built as interconnected and radial system networks. The distribution system is considered as the weakest part in the power sectors (Generation, Transmission and Distribution) that mainly deal directly amongst the customers with different paying (tariff) levels. The distribution losses in Nigeria cannot be used to equate the power losses of the developed countries due to the system operating requirement which differs in different countries.

Out of the six privatized generation companies of Nigeria (GENCOs), two uses hydro and four uses thermal as their plant type. The Nigerian Electricity Supply Industry (NESI) presently has twenty-three (23) grid connected generating plants that are in operation with a total installed capacity and available capacity of $10,396 M W$ and $6056 M W$ respectively. The four thermal based generation companies namely Afam Power Plc., Egbin Power PLC, Sapele Power PLC and Ughelli Power PLC take about $81 \%$ of the total installed capacity $(8457.6 \mathrm{MW})$ and $83 \%$ of total available capacity $(4996 M W)$. The two other major hydro based generation companies such as Kainji/Jebba Hydro electric Plc. and Shiroro hydro electric Plc. have its total installed capacity of $1938 M W$ and total available capacity of $1060 M W$ [2].

Subsidized and frequent unmetered power consumed contributes to distribution utility problems in terms of technical losses, billing of customers, recovery of debt (arrears) and consumption habits. Since the metering, billing of customers and collections at many locations always require presence of the personnel (employee), most times human mistake, intentional or non-intentional occur [15].

[12] Used four different methods in their work which include Viera-Bonessi method, 3G-3D method, Monthly block method and proposed method to estimate annual technical power loss in distribution feeders as a result of distribution generation (DG) connection. It was also stated in their work that the main challenge in power loss evaluation is the non-linear relationship with power injections in the network buses. Viera-Bonessi method was used for planning of distribution networks and it is developed for three main sources of power such as biomass, hydropower and wind. In their work, only the wind type method was considered to calculate the annual energy losses of the network and the peak (maximum) demand, average demand and minimum demand of power duration curve and annual active power demand curve. Monthly blocks method produces monthly demand curve with the active and reactive power hourly demand curve at the feeder head and the 'Proposed method (approach)' was used to create a demand duration curve based on the active power.

In their work, Seethalekshmi K. considered two approaches which include 'Technical loss evaluation strategy' and 'sampling procedure' [26]. The technical loss evaluation approach is mainly applied on the feeders (distribution lines) to check the theoretical losses and assess the technical losses which resulted to the computation of commercial losses because of bad metering. In 'Sampling method', the parameters focused upon was the practical possibility (feasibility) and time frame needed to achieve the exercise. The technical loss evaluation approach carried out in their work are as follow:

1. Detailed survey at selected distribution transformer centres (DTC) for energy accounting.

2. Evaluation of commercial loss $\left(I^{2} R\right)$ for the selected distribution transformer (DTR).

3. Estimate of commercial loss from the technical loss.

4. Extrapolate the method to other distribution transformer centres (DTCS) based on the total number of connected consumers, route length of low tension line and transformer capacity.

5. Compute the net technical loss due to low tension (for the peak time).

6. Estimate the transformer loss having determined the percentage loading of the transformer.

7. Estimate the high tension loss from load flow.

8. Summation of the estimated transformer losses (with known percentage loading of the transformer) and estimated high tension losses from load flow yield the net technical loss in the $11 \mathrm{kV}$ or $33 \mathrm{kV}$ feeder during peak periods (hours).

9. Estimate Yearly (Annual) Technical energy loss from the relation. 
Annual Energy loss $=$ Peak power loss $\times$ Loss Load factor

Loss Load Factor $=0.8 \times L F^{2}+0.2 \times L . F$

load factor $=$ Actual load $/$ Maximum load

Commercial loss $=$ Total energy sent - (total energy billed + Technical loss).

The sampling approach considered on the distribution transformer centre (DTC) was based on;

1. Rating of connected transformer.

2. Transformer loading and low tension $(L T)$ route length associated with the DTC .

3. Level of consumption and class of the consumers connected.

Navani. J. P Analysed technical and commercial losses in power system using Newton-Raphson method of load flow studies stimulated under MAT-LAB environment to simply compute the technical and then non-technical losses [17]. In their work, the extra load profile gave negative power factors because the non-technical loss is assumed to be inductive.

In their work on 'Evaluation of losses in Distribution Networks', Hachimenum N. Amadi stated that NewtonRaphson approach using Electrical Transient and Analysis Program (ETAP) software of version 12.6 has the characteristics (attribute) to converge fast and it depends much on the bus voltage initial values. The convergence criteria are mainly set to $0.001 M W$ and Mvar and this technique can be used in power flow studies when the bus voltages are put in polar form. The ETAP software causes a few Gauss - Seidel iterations to produce a set of sound initial values for the bus voltage but Newton-Raphson approach is frequently considered for use with most systems.

The method of analysis applied in their work is a 'Load Flow-Based Technique' using Newton Raphson Load Flow technique for the simulation in ETAP 7.0 environment. [21] The fundamental heuristic approach followed in their work includes:

1. Modelling of the feeder (network) configuration.

2. Run load flow for the base-case.

3. Re-adjust if any, for necessary error of transformer capacity and tap setting for possible simulation.

4. Identify the bus voltage margins, branch power flow and losses.

5. Integrate sizeable distributed generations (DGs) into the network busses.

6. Make priority list for voltage margins and the power losses from the results obtained, etc.

According to [23], the statistical analysis used in their work to determine the energy loss in the electric utilities involves two vital factors namely load factor $(L F)$ and loss factor $\left(L_{S} F\right)$. Their work involved much analysis of different load curves and statistical evaluation approach. An extensive analysis with real life load curve was presented, determining new values for constant coefficient, $k$ of a wide range of electric utilities.

Loss Factor is the ratio of the average power loss over a particular time and the peak load power loss in that same period of the time. Mathematically, the loss factor equation is given as

$$
\begin{gathered}
L_{\mathrm{S}} \mathrm{F}=(\mathrm{L} . \mathrm{F}) \mathrm{K}+(\mathrm{LF})^{2}(1-\mathrm{K}) \\
L_{S} F=\frac{L_{\text {average }}}{L_{\max }}=\frac{1}{L_{\max }} \frac{\int_{0}^{T} L(t) d t}{T} \\
L_{S} F=\frac{e}{L_{\max } T} \\
\int_{0}^{T} L(t)=\text { instanteneous demand }
\end{gathered}
$$

or energy supplied to the system (E) during the period of the time $\mathrm{T}$.

Load Factor is the ratio of the average power and the greatest demand in a particular time. It is mainly derived with energy and demand management. Load factor is expressed by

$$
\begin{gathered}
L F=\frac{D_{\text {average }}}{D_{\max }}=\frac{1}{D_{\max }} \frac{\int_{0}^{T} D(t) d t}{T} \\
L F=\frac{E}{D_{\max T}} \\
\int_{0}^{T} D(t) d t=\text { instanteneous demand }
\end{gathered}
$$

or energy supplied to the system (E) during the period of the time $\mathrm{T}$.

In their work, Hachimenum N. Amadi presented an appropriate statistical table (data) and charts [6]. These raw information were simulated on the 'Electrical Transient and Analysis Program (ETAP)' version 12.6 software and the simulation outcomes were applied to the computation of energy losses and the equivalent revenue losses in the different distribution networks. Mathematically, the total revenue loss, $R_{\text {loss }}$ can be express as;

$$
R_{\text {loss }}(\#)=C_{e}(\# / k W h) \times E_{\text {losses }}(k W h)
$$

According to [22] in their work, the methodology for calculating technical losses in distribution system are divided into eight different segments namely; 1. Energy meter 2. Customer connections to the distribution feeder (network). 3. Low voltage network. 4. Distribution transformers. 5. Medium voltage network. 6. Distribution substations. 7. Subtransmission system. 8. And other part of technical losses such as equipment loss in capacitors, voltage control (regulators), connectors, non-conductive materials (insulators) etc.

The steps of the approach considered in their work stated that;

1. Every energy meter is given a fixed value of losses based on its type.

2. Using typical customer daily load curves, losses in customer connection are checked by assuming specific parameters like length and electric resistance of standard conductors. 
3. Three-phase load flow approach for every moment in the daily load curve were used for each low voltage feeder tied to a transformer, energy and demand losses.

4. Copper and iron losses in every distribution transformers are calculated, such indices are gotten from the rated parameter of the transformer and from their various load curves, calculated by the aggregation of daily curve of every customer tied to the transformer via the low voltage network.

5. Technical losses in megavolt distribution network are analysed (evaluated) by a three-phase load flow programme by using aggregated transformer load curves got on the transformer incomer (primary side).

6. The above techniques are used for all megavolt outgoing feeder in a distribution substation.

7. Energy losses are the determined at the subtransmission network, putting into account the customers supplied at this stage.

8. The measured energy at the supplied point minus the sum of billed energy and energy losses is given as the commercial losses summed up to other losses.

Mufutau W. O Used 'Loss factor approach' in their work and revealed that the distribution network should be expanded by installation of an additional distribution transformer to reduce long feeder route length [13]. They applied equations on sample network data for power transformer losses and feeder line loss. The power transformer losses equation is expressed as:

$$
\text { Loss Factor, } L_{f}=\frac{K V A_{\text {average }}}{K V A_{\text {Max Demand }}}
$$

Lad Factor, $L_{l f}=\frac{\text { Actual loss during a period }(k W h)}{\text { Loss at Maximum current }(k W h)}$

The load factor and loss factor relationship are give as

$$
L_{l f}=K \times L_{f}+(1-K) \times\left(L_{f}\right)^{2}
$$

where $\mathrm{K}=$ Coefficient of loading.

$$
K=\frac{\text { Maximum Demand }\left(K V A_{\min }\right)}{\text { Maximum Demand }\left(K V A_{\max }\right)}
$$

The total power loss in the power transformer $\left(W_{\text {TLoss }}\right)$ in $\mathrm{kW}$ is expressed as

$$
W_{T L o s s}=\left\{\begin{array}{c}
\text { Load loss }\left(W_{L}\right)+ \\
\text { No Load loss }\left(W_{N L}\right)
\end{array}\right\} \times 10^{-3}
$$

where

$$
\begin{gathered}
W_{L}=W_{C}\left(\frac{K V A_{\text {MaxDemand }}}{K V A_{\text {Rating }}}\right)^{2} \times L_{l f} \\
W_{C}=\text { Full load copper loss } \\
K V A_{M D}=\text { Maximum KVA Demand in a period } \\
K V A_{\text {Rating }}=\text { KVA rating of the transformer }
\end{gathered}
$$

Combining $W_{\text {TLoss }}$ and $W_{L}$ together, we have

$$
W_{\text {TLoss }}=\left\{W_{C}\left(\frac{K V A_{\text {MaxDemand }}}{K V A_{\text {Rating }}}\right)^{2} \times L_{l f}+W_{N L}\right\}
$$

The feeder line loss is expressed as;

$$
P_{\text {Loss }}=I_{L}^{2} R
$$

Where $P_{\text {Loss }}=$ power loss on a feeder

Considering loss factor,

$$
\begin{gathered}
P_{\text {Loss }}=I_{L}{ }^{2} R \times(\text { Loss factor }) \\
\text { Loss factor }= \\
(0.3 \times \text { load factor })+0.7 \times(\text { load factor })^{2}(20)
\end{gathered}
$$

Load factor $=($ Average load $)($ Peak load $)$ Maximum current $\left(I_{L}\right)$ in Ampere, drawn from feeder is expressed as

$$
I_{L}=\frac{P}{\sqrt{3} V \times p f}
$$

The resistance of the line, $R(\Omega)$ is equal to

$$
R=\rho l / A
$$

Substituting Loss factor, $I_{L}$ and $R$ into $P_{\text {Loss, }}$ we have

$$
\begin{gathered}
P_{\text {Loss }}=\frac{P^{2} \rho l}{3 A(V \times p f)^{2}}\{(0.3 \times \text { load factor })+0.7 \times \\
\left.(\text { load factor })^{2}\right\}
\end{gathered}
$$

The total power in the system is given as

$$
\begin{gathered}
\text { Total loss }=W_{\text {TLoss }}+P_{\text {Loss }} \\
\text { Then, Total Loss }=\text { constant }+P_{\text {Loss }}
\end{gathered}
$$

Working Group of Loss Reduction Stated in their work that non-technical losses mitigation can be evaluated and enhanced by two kinds of data mining techniques such as 'Statistical regular approach' and 'Big data and smart meter method'. Data mining is mainly used to optimize inspection in the field by steering them to definite locations fraud is suspected [28]. Big data and smart meter method detect events like meter tempering. Component method (connectors, low loss transformer, superconductors etc.), Feed-in-Control method and Grid Management method were used on the technical losses and finalized that the evaluation of the different types of the technical loss shows that technical losses structure and level are very specific to each distribution network.

In Khalil Y. A's work on 'Power System Losses Evaluation and Estimation' [9], the energy losses in the network should be calculated by extrapolating the daily energy loss proportional to the energy supplied in the feeder, for all feeder and for all the months in the audit period. The technique carried out in his work include the following;

1. Manual Evaluation Computation

2. Microsoft Excel Sheet and

3. Power System Analysis Tool (PSAT) Software

According [1] in their work, Newton-Raphson Load Flow method was used to first evaluate technical losses, and then revealed that non-technical (commercial) losses cannot be 
calculated and measure absolutely, but can be assessed by removing technical losses from the entire network losses. The authors also modelled the network of their work with the application of NEPLAN software which involves opening of dialog boxes and inputting all the relevant parameters. The link between power system network aggregate technical and commercial losses $\left(P_{A T C}\right)$, Technical losses $\left(P_{T L \text { Losses }}\right)$ and Non- technical (commercial) losses $\left(P_{N T L \text { Losses }}\right)$ are expressed as;

$$
\begin{gathered}
P_{A T C \text { LOSSES }}=P_{T L \text { LOSSES }}+P_{N T L \text { LOSSES }} \\
P_{\text {NTL LOSSES }}=P_{A T C \text { LOSSES }}-P_{T L \text { LOSSES }} \\
P_{\text {ATC }}=P_{\text {ESTIMATED }}-P_{\text {OUTPUT }}
\end{gathered}
$$

Nwohu M. N. Revealed that the technique to evaluate 'Aggregate Technical, Commercial and Collection.

Losses $(A T C \& C)$ ' Is to explore through comprehensive field survey and critical study of the network diagram in order to identify various feeders and energy input and output point of the location [19].

\subsection{Resistive Losses}

According to [3] in their work, the quantity of resistive loss in a power system can be found connected by applying corona-free transmission/distribution feeder equations to determine and evaluate the quantity of power supplied to any point along the conductor and removing the initial quantity of power. The expression of the resistive losses is given by;

$$
\begin{gathered}
P_{(Z)}=P_{(0)} e^{-2 \alpha Z}=P_{(0)} e^{-z R_{l} /(L C)} \\
P_{R \text { LOSS }}(0: Z)=P_{(0)}-P_{Z} \\
\% P_{R \text { LOSS }}=\frac{P_{(0)}-P_{(Z)}}{P_{(0)}}=1-e^{-L R_{l} /(L C)}
\end{gathered}
$$

Inductance per unit length of the line is equals to

$$
\begin{gathered}
L=\frac{\mu}{\pi} \operatorname{In}\left(\frac{d}{a}\right) \\
\delta=\frac{1}{\sqrt{\pi f \mu_{0} \sigma}} \\
R_{l}=\frac{I_{B}}{2 \pi \alpha \sigma \delta}
\end{gathered}
$$

where

$$
\begin{aligned}
& C=\text { Speed of light } \\
& \mu_{0}=\text { Permeability of free space } \\
& \alpha=\text { Conductor radius } \\
& d=\text { Line separation } \\
& L=\text { Inductance per meter } \\
& I_{B}=\text { Bassel Correction Factor }
\end{aligned}
$$

Applying the above expression, the net quantity of power lost due to resistance is equal to the power at a particular distance subtracted by the initial power.

According to [20] in their work, they presented two methods to determine technical energy losses. These include;

1. An approach based on subtraction of metered energy bought and metered energy sold to customers by checking the load curve, field survey and data record.

2. Method based on modelling losses in industrial components of the system.

In Narong M.'S work, he analysed technical losses in distribution line system with calculations and PSS/Adept 5.0 program [14]. The equations used for the analysis of the distribution line losses is given by;

$$
\begin{gathered}
\text { Distribution line losses }(k W h)=\text { Loss Factor } \times \\
\text { Line Losses } \times \text { period }
\end{gathered}
$$

when Loss Factor $=0.33 L F+0.67 L F^{2}$

$$
\text { Load Factor }(L F)=\frac{\text { Average Load }\left(k W_{\text {avg }}\right)}{\text { Peak Load }\left(k W_{\text {peak }}\right)}
$$

Line Losses from model PSS/(Adept 5.0)

In their work, Iderjeet S. S. evaluated technical and nontechnical losses in power system by analytical techniques with MATLAB simulation [8]. The analysis carried out on non-technical loss is expressed by the equations; Energy Losses is equal to Energy delivered minus Energy sold

$$
E_{\text {loss }}=E_{\text {delivered }}-E_{\text {sold }}
$$

Revenue Loss due to tecnical losses

$$
C_{\text {com.loss }}=\left(U_{\text {elect.cost }} \times E_{\text {loss }}\right)+M_{\text {maintenance cost }}
$$

Non-technical Loss is expressed as;

$$
C_{N T L}=C_{\text {com.loss }}-C_{\text {Technical loss }}
$$

where

$U_{\text {Elect.cost }}=$ Unit cost of electricity.

The authors revealed that technical loss in power system occur as a result of equipment inefficiency and stated that noload losses (core losses) which include hysteresis and eddy current losses is considered and expression of these losses is given by:

$$
\begin{gathered}
\text { Hysteresis Loss, } P_{H}=K_{h} f B_{m} \\
\text { Eddy current loss, } P_{E}=K_{e} f^{2} B_{m}^{2}
\end{gathered}
$$

where

$$
\begin{aligned}
& f=\text { frequency } \\
& B_{m}=\text { flux density of the core material } \\
& K_{h}, K_{e}=\text { Hysteresis \& Eddy current constant. }
\end{aligned}
$$

Navani J. P. analysed technical and non-technical losses by simply calculated the technical losses using 'Load Flow Method of Power System' simulated under Mat-Lab environment [16]. In their work, the outcome of technical losses were first calculated and minuses from the net losses to determine the remaining value as non-technical losses because non-technical losses are much harder to measure.

According to [24] correct calculations of losses are vital for many reasons. The two methods used to compute technical energy losses in their work include;

1. Method based on subtraction of metered energy bought and metered energy sold to customers.

2. Method based on modelling losses in individual 
components of the system.

And Visual Basic program was designed to compute and evaluate electrical energy losses in electrical energy systems. The equations used in their work to calculate and evaluate distribution line losses $(33 / 11 \mathrm{kV})$ and distribution transformer losses can be express as;

$$
\begin{gathered}
P_{L}=3 \times I^{2} \times R \times L \times 10^{-3} \\
a=\frac{\sqrt{3} \times V_{L} \times I_{\text {total }}}{S_{\text {total }}} \\
P_{T}=n\left[\left(a^{2} \times P_{c}\right)+P_{i}\right]
\end{gathered}
$$

where

$$
\begin{aligned}
& R=\text { Line resistance }(\Omega / \mathrm{km}) \\
& P_{L}=\text { Line losses }(\mathrm{kW}) \\
& I=\text { Total current flow }(A) \\
& L=\text { Length of the line }(\mathrm{km}) \\
& P_{T}=\text { Transformer losses }(\mathrm{kW}) \\
& P_{c}=\text { Copper losses }(\mathrm{kW}) \\
& P_{I}=\text { Iron losses }(\mathrm{kW})
\end{aligned}
$$

In their work, Kulkarni V. A. Stated that energy losses of power system are determined by two methods namely 'Actual readings' and 'Analytical calculations'[10]. Combining these stated methods are the best approach to estimate and evaluate the best possible losses near to accuracy and they are mainly applied on losses in the transformer circuit in a feeder. The approach applied on the distribution transformer is expressed as:

$$
\operatorname{Tr} k V A_{\text {total }}=\text { Total rating of all transformer } k V A
$$

$$
\operatorname{Tr}_{\text {En Loss }}=\left(W_{i}+W_{w d g}+W_{o t h e r}\right) T
$$

Total transformer Energy Loss $=\sum_{i=1}^{n} \operatorname{Tr}_{\text {En Loss }(i)}$

\section{Where;}

$\operatorname{Tr}_{\text {En.loss }}=$ Transformer Energy Loss

$T=$ Period of consideration

$W_{i}=$ No Load Losses(hysteresis, Eddy current etc.)

$W_{w d g}=$

Winding loss or Load loss $\left(I^{2} R\right.$ and stay losses)

$W_{\text {other }}=$ Other losses (dielectric loss etc.)

\subsection{Equation for Calculation of Power Losses in Low Voltage Distribution Network}

In their work, Marwan M. M. adopted a mathematical equation to calculate and evaluate power losses in low voltage distribution networks by considering the source [11].

Let,

$I_{1}, I_{2} \ldots I_{n}=$ the load current per consumer(resident)

$Z_{1}, Z_{2} \ldots Z_{n}$

$=$ the impedance of respective distributor length

$$
\begin{aligned}
& \left(I_{1}, I_{2} \ldots I_{n}\right) \cos \emptyset_{1}, \cos \emptyset_{2} \ldots \cos \emptyset_{n} \\
= & \text { the power factor of each consumer } \\
& Z_{k}=R_{k}+j X_{k}(k=1 \ldots n)
\end{aligned}
$$

The total active power losses in the distributor $(\Delta P)$ is given as;

$$
\begin{gathered}
\Delta P=R_{1}\left(I_{1}+I_{2} \ldots I_{n}\right)^{2}+R_{2}\left(I_{2}+I_{3} \ldots I_{n}\right)^{2}+R_{k}\left(I_{K}+\right. \\
\left.I_{k+1} \ldots I_{n}\right)^{2}+R_{n} I_{n}{ }^{2} \\
\Delta P=\sum_{k=1}^{n} R_{k}\left[\sum_{j=k}^{n} I_{j}\right]^{2}
\end{gathered}
$$

The load current $\left(I_{j}\right)$ injected into bus $j$ is given by;

$$
I_{j}=\frac{P_{j}}{V_{j} \cos \emptyset_{j}}
$$

Substituting eqn 49 in eqn 48, we have

$$
\Delta P=\sum_{k=1}^{n} R \backslash_{k}\left[\sum_{j=k}^{n} \frac{P_{j}}{V_{j} \cos \emptyset_{j}}\right]^{2}
$$

Where,

$n=$ the number of buses in the distributor.

$V_{J}=$ Voltage at bus $j$

$P_{j}=$ Power at bus $j$

$R_{k}=$ the resistance of the distributor branch $k$ $\cos \emptyset_{j}=$ the power factor for $j$ load.

Eqn. 50 shows that the power losses are inversely proportional to the power factor square and the minimum losses $\Delta P_{\text {min }}$ are obtained at $\cos \emptyset=1$.

$$
\Delta P=\sum_{k=1}^{n} R_{k}\left[\sum_{j=k}^{n} \frac{P_{j}}{V_{j}}\right]^{2}
$$

Considering $\Delta P_{\min }$ as a reference, we have the power losses in

$$
\begin{gathered}
\text { per unit form }\left(\Delta P^{*}=\Delta P / \Delta P_{\text {min }}\right) \\
\Delta P^{*}=\sum_{k=1}^{n} \frac{1}{\cos \emptyset_{j}}
\end{gathered}
$$

Then, the voltage drop along the distribution network is given by;

$$
\Delta V_{j}=\left|Z_{j}\right| \frac{P_{j}}{V_{j} \cos \emptyset_{j}}
$$

The minimum voltage drop is achieved also when $\cos \emptyset_{j}=1$ Taking this case as a reference we obtain the voltage drop in per unit form $\left(\Delta V^{*}\right)$

$$
\Delta P_{j}^{*}=\frac{1}{\cos \emptyset_{j}}
$$

Eqn. 55 show that the voltage drop along the distribution network is inversel proportional to $\mathrm{P}$. $\mathrm{F}$ at the individual bus. The total active and reactive power $\left(P_{s}, Q_{s}\right)$ delivered by the source is given as;

$$
\begin{array}{r}
P_{s}=\sum_{j=1}^{n} P_{j}+\Delta P \\
Q_{s}=\sum_{j=1}^{n} Q_{j}+\Delta Q
\end{array}
$$

Where,

$\Delta \mathrm{P}$ and $\Delta \mathrm{Q}=$ the total active and reactive power losses in the distribution network. The power factor (P. F) of the $j$ 
household load is related to the corresponding $P_{j}$ and $Q_{j}$ as;

$$
\cos \emptyset_{j}=\cos \tan ^{-1}\left(Q_{j} / P_{j}\right)
$$

Besides, reduction of active and reactive power losses, by improving the power factor, keeping the voltages $V_{j}$ within an acceptable range $\left(V_{\text {jmin }} \leq V_{j} \leq V_{\text {jmax }}\right)$ should also be considered.

\subsection{Losses in Power Distribution System}

Distribution losses are the different between the energy received from the source and energy billed to customers for a particular range of time. Power distribution system losses are mainly expressed in terms of percentage of purchase and sold and it focused much on the electric utilities due to the lost revenue from power and energy bought from electric power producers but not sold.

\subsection{Types of Losses in Power Distribution Networks}

Power distribution system in Nigeria mainly consists of two major types of losses which include:

1. Technical losses.

2. Non-technical losses or Commercial losses.

\subsubsection{Technical Losses}

Technical losses are those losses which occur in power system networks due to electric energy dissipated via the equipment necessary for the distribution system or when electric current flows via resistive materials and magnetizing energy in the feeders (distribution lines), power and distribution transformers and other electric power equipment. These losses occur due to the network design, equipment design, and equipment specifications, drop in equipment efficiency, network configuration and its operation parameters (measurement systems).

\subsubsection{Non-Technical (Commercial) Losses}

Commercial (Non-technical) losses are those used energy which are not billed or paid for due to meter bypass, meter tampering, measurement equipment failure, energy theft (loss of revenue), billing error, inaccurate or wrong meter reading, delay in meter reading and billing, neglecting of arrears or unpaid debt, bad meters, failure to pay bills by customers etc. It is more challenging to measure these losses because they are not frequently put into consideration by the distributions.

\subsection{Statistical Analytical Method with Microsoft Excel}

In this work, a lot of large values (data) are involved and high accuracy is needed. A statistical analytical method with Microsoft excel sheet is used in this work to evaluate the technical and non-technical (commercial) losses because it has higher accuracy than other approaches. With the statistical table applied in the methodology for one year, an excel sheet is easily used to subtract the output power billed from the input power supplied, estimate and calculate technical and commercial losses, compute monthly and annual revenue losses which have larger energy values. In this work, there will be charts and graphs to show the level of losses encountered monthly on each feeder so as to derive a means to minimize the losses.

\section{Methodology}

The methodology framework of this work are data collected and its presentation, the value of energy supplied, energy billed and computing of distribution losses, technical losses estimation and calculating of commercial (nontechnical) losses for one year.

\subsection{Collection of Data}

Akani Injection substation of the Port Harcourt Electricity distribution company has $2 \times 15 M V A$ power transformers, $24 \mathrm{MW}$ station capacity, route length of $0.22 \mathrm{Km}$ (underground $0.21 \mathrm{Km}$, overhead $0.01 \mathrm{Km}$ ), No line load distribution transformer, and six $11 \mathrm{kV}$ feeders which include Rumuogba, Rumurolu, Old Aba Road, Glass Factory, Rumukalagbor and Rumuibekwe. Three $11 \mathrm{kV}$ lines radiates from each $15 M V A$ transformers. These $11 \mathrm{kV}$ networks radiated from Akani Injection Substation feed from the Akani $33 \mathrm{KV}$ feeder (underground) which sourced from $T_{1} A$ 60MVA power transformer in transmission station, Trans Amadi, Port Harcourt (Port Harcourt Mains). The $11 \mathrm{kV}$ distribution networks have different system components such as line conductors $\left(150 \mathrm{~mm}^{2}, 100 \mathrm{~mm}^{2}\right.$ and $\left.75 \mathrm{~mm}^{2}\right)$, Isolators, Circuit breakers, feeder pillars $(800 \mathrm{~A}), 0.415 \mathrm{kV}$ lines and distribution transformers.

\subsection{Presentation of Data}

The data of six (6) $11 \mathrm{kV}$ distribution networks which include Rumuogba, Glass Factory, Old Aba Road, Rumurolu, Rumukalagbor and Rumuibekwe were taken for one year to evaluate the supplied energy, billed energy and energy loss. On Glass Factory feeder, the total number of transformers in the network are nineteen (19). That is, 1 No. $\times 300 \mathrm{kVA}, 17$ No. $\times 500 \mathrm{kVA}, 1 \mathrm{No} . \times 800 \mathrm{kVA}$ and the total route length of the network is $17.065 \mathrm{~km}$ (underground $5.215 \mathrm{~km}$, overhead $11.85 \mathrm{~km}$ ) that is, the summation of all Toffs and line distance. The total number of distribution transformers on Rumuogba, Rumurolu, Old Aba Road, Rumukalagbor and Rumuibekwe are $25(19 \times 500 \mathrm{kVA}, 6 \times$ $300 k V A), 17(17 \times 500 k V A) \quad, \quad 26(19 \times 500 k V A, 6 \times$ $300 k V A, 1 \times 200 k V A), 16$ and $8(1 \times 300 k V A, 7 \times$

$500 \mathrm{kVA}$ ) respectively. In addition, the total route length of Rumuogba, Rumurolu, Old Aba Road, Rumukalagbor and Rumuibekwe are $15.004 \mathrm{~km}$ (U/G $0.254 \mathrm{~km}, \mathrm{O} / \mathrm{H} 14.75 \mathrm{~km}$ ), $12.985 \mathrm{~km}(\mathrm{U} / \mathrm{G} 0.025 \mathrm{~km}, \mathrm{O} / \mathrm{H} 12.96 \mathrm{~km}), 17.325 \mathrm{~km}$ $(\mathrm{U} / \mathrm{G} \quad 0.045 \mathrm{~km}, \mathrm{O} / \mathrm{H} 12.96 \mathrm{~km}), 5.1 \mathrm{~km}$ and $2.3 \mathrm{~km}$ respectively. The average cost of energy purchased and sold in Naira per kilowatt-hour $(\# / k W h)$ from the Distribution Company used in this work include $\# 19$ and $\# 30.82$ respectively. 


\subsection{Computing Distribution Losses on the Feeders}

Distribution losses which include the technical and commercial losses are the energy supplied at the input point minus energy billed to customers in kilowatts-hour and in percentage for a particular period.

1) Billing efficiency $=$ Energy billed/Energy received

2) Collection efficiency $=$ Amount recovered/Amount Billed

3) ATC\&C loss $=[1-($ Billing efficiency $\times$ Collection efficiency) $\times 100]$

In the distribution network, the total energy supplied, $E_{S}$ in kilowatts-hour $(k W h)$ and total energy billed, $E_{b}$ are considered to get the total energy loss, $E_{l}$ and the percentage loss of the energy $E_{l} \%$ on the system. The total distribution losses in the system can be evaluated by comparing the result of energy delivered by the injection substation and total energy billed during the stipulated period of time. The mathematical equation of the Energy loss and its percentage loss are given by;

$$
\begin{aligned}
& E_{l}=E_{s}-E_{b} \\
& E_{l} \%=\frac{E_{l}}{E_{S}} \times \frac{100}{1}
\end{aligned}
$$

The net energy supplied per month, $E_{S}$ is determined by summing the respective daily energy readings from the system. The total energy supplied to the feeders for the period of one year is stated below.

Table 1. Total Energy Supplied, Es for the period of one year (1yr) 2017-2018.

\begin{tabular}{llllllll}
\hline SN & Month & Glass Factory & Old Aba Road & Rumuogba & Rumurolu & Rumukalagbor & Rumuibekwe \\
\hline 1 & Jul. & 828035.03 & 716450.00 & 1131932.14 & 1066050.00 & 547700.09 & 640400.23 \\
2 & Aug. & 843432.54 & 842584.00 & 1131932.14 & 961510.76 & 500100.26 & 593400.12 \\
3 & Sept. & 713266.26 & 1634732.47 & 1002087.94 & 1065833.33 & 538600.17 & 555500.06 \\
4 & Oct. & 665374.05 & 642994.00 & 1131932.14 & 1076997.54 & 580800.62 & 694900.70 \\
5 & Nov. & 1493655.00 & 1130762.00 & 1131932.14 & 1146671.03 & 656800.13 & 651000.39 \\
6 & Dec. & 830833.99 & 1126042.00 & 956988.23 & 1009998.49 & 671800.11 & 667000.28 \\
7 & Jan & 1338953.41 & 1287522.57 & 1329273.39 & 1712440.63 & 562400.33 & 565000.05 \\
8 & Feb. & 1191065.06 & 1187159.10 & 1059144.49 & 1715471.36 & 456800.17 & 501800.60 \\
9 & Mar. & 776808.50 & 1129968.33 & 983742.74 & 1353600.44 & 671400.15 & 622500.37 \\
10 & Apr. & 1128481.05 & 1570123.39 & 1390288.65 & 1451316.91 & 544800.71 & 505900.90 \\
11 & May & 773085.47 & 1347751.07 & 1208220.83 & 1356312.63 & 628800.26 & 620700.80 \\
12 & Jun. & 1027890.00 & 1981349.41 & 1214563.48 & 1291824.98 & 628800.12 & 620700.00 \\
\hline
\end{tabular}

The value of the energy billed for the period of one year on these six $11 \mathrm{kV}$ outgoing feeders from the injection substation are stated in the table. The energy billed cut across the residential, street light, commercial and industrial consumers of the feeders.

\begin{tabular}{|c|c|c|c|c|c|c|c|}
\hline $\mathbf{S} \mathbf{N}$ & Month & Glass Factory & Old Aba Road & Rumuogba & Rumurolu & Rumukalagbor & Rumuibekwe \\
\hline 1 & Jul. & 390373.00 & 401050.00 & 739530.00 & 521350.00 & 445687.10 & 291124.27 \\
\hline 2 & Aug. & 414091.00 & 437891.60 & 545445.06 & 534707.00 & 425885.07 & 321033.16 \\
\hline 3 & Sept. & 321317.00 & 346915.98 & 627422.44 & 632306.00 & 317999.80 & 281373.22 \\
\hline 4 & Oct. & 743554.76 & 524571.49 & 585542.72 & 662552.00 & 362956.03 & 332344.18 \\
\hline 5 & Nov. & 486917.00 & 537409.30 & 535503.00 & 601805.00 & 377631.85 & 388976.16 \\
\hline 6 & Dec. & 687680.00 & 608133.90 & 656100.60 & 789023.60 & 274532.55 & 402871.30 \\
\hline 7 & Jan. & 569247.70 & 598421.00 & 642272.00 & 791191.30 & 401260.83 & 418204.40 \\
\hline 8 & Feb. & 368946.00 & 727096.00 & 492957.00 & 655026.00 & 359045.34 & 370002.10 \\
\hline 9 & Mar. & 549433.00 & 863036.00 & 674595.00 & 687066.00 & 360823.52 & 330431.23 \\
\hline 10 & Apr. & 367280.47 & 708132.00 & 683243.00 & 628072.00 & 338461.31 & 314294.26 \\
\hline 11 & May & 501114.12 & 935762.00 & 644409.00 & 595948.00 & $349068.09^{\prime}$ & 334592.41 \\
\hline 12 & Jun. & 415746.26 & 761351.00 & 590958.03 & 495366.00 & 321907.38 & 327943.52 \\
\hline
\end{tabular}

Table 2. Total Energy billed, $E_{b}$ for the period of one year (1yr) 2017-2018.

The distribution losses and percentage losses of the six $11 \mathrm{kV}$ feeders calculated per month for the period of one year are given by;

Energy loss on Glass factory feeder for July, 2017

$$
\begin{gathered}
E_{l}=828,035.03-390,373.00 \\
E_{l}=437,662.03 \\
E_{l} \%=\frac{437,662.03}{828,035.03} \times \frac{100}{1}=52.85 \%
\end{gathered}
$$

$$
E_{l} \%=52.85 \%
$$

Commercial (NTL) Losses;

$$
N T L=E_{I}-T_{L}
$$

That is, Non-technical losses in $\mathrm{kWh}=$ Distribution lossesTechnical losses

Percentage commercial (Non-technical) losses;

$$
N T L \%=\frac{N T L}{E_{I}} \times \frac{100}{1}
$$




\section{Results and Analysis}

\subsection{Presentation of Data}

The results of these six $11 \mathrm{kV}$ feeders obtained for a period of one year; distribution losses and its percentage losses, technical losses $(k W h)$, non-technical losses $(k W h)$ and its percentage losses, monthly revenue losses (technical and commercial) and total annual revenue losses are stated below.

Table 3. Result of energy supplied, distribution losses, Technical losses and commercial losses (NTL) for Jul., 2017.

\begin{tabular}{llllll}
\hline Feeder & $\mathbf{E}_{\mathbf{s}}(\mathbf{k W h})$ & $\mathbf{E}_{\mathbf{l}}(\mathbf{k W h})$ & $\mathbf{E}_{\mathbf{l}} \mathbf{\%}$ & $\mathbf{T}_{\mathbf{L}}$ & $\sim$ NTL \\
\hline Glass Factory & 828035.03 & 437662.03 & 52.85 & 38287.34 & 399374.69 \\
Old Aba Road & 716450.00 & 315400.00 & 44.02 & 14892.73 & 300507.27 \\
Rumuogba & 1131932.14 & 392402.14 & 34.67 & 38241.4 & 354160.74 \\
Rumurolu & 1066050.00 & 574700.00 & 51.09 & 33902.54 & 54.25 \\
Rumukalagbor & 547700.09 & 102012.99 & 18.63 & 31495.20 & 70517.79 \\
Rumuibekwe & 640400.23 & 349275.96 & 54.50 & 34182.24 & 315093.72 \\
\hline
\end{tabular}

Table 4. Result of energy supplied, distribution losses, Technical losses and commercial losses (NTL) for Aug., 2017.

\begin{tabular}{|c|c|c|c|c|c|c|}
\hline Feeder & $E_{s}(k W h)$ & $E_{l}(k W h)$ & $E_{1} \%$ & $\mathbf{T}_{\mathrm{L}}$ & $\sim$ NTL & $\sim$ NTL\% \\
\hline Glass Factory & 843432.54 & 429341.54 & 50.90 & 40149.72 & 469191.82 & 90.60 \\
\hline Old Aba Road & 842584 & 404692.4 & 48.02 & 19736.32 & 404956.08 & 95.12 \\
\hline Rumuogba & 1131932.14 & 586487.08 & 51.81 & 33625.41 & 552861.67 & 94.27 \\
\hline Rumurolu & 961510.76 & 426803.76 & 44.39 & 39238.46 & 387565.30 & 90.81 \\
\hline Rumukalagbor & 500100.26 & 74215.19 & 14.84 & 32728.09 & 41487.10 & 55.90 \\
\hline Rumuibekwe & 593400.12 & 272366.96 & 45.89 & 33731.56 & 238635.40 & 87.62 \\
\hline
\end{tabular}

Table 5. Result of energy supplied, distribution losses, Technical losses and commercial losses (NTL) for Sept., 2017.

\begin{tabular}{lllllll}
\hline Feeder & $\mathbf{E}_{\mathbf{s}}(\mathbf{k W h})$ & $\mathbf{E}_{\mathbf{l}}(\mathbf{k W h})$ & $\mathbf{E}_{\mathbf{l}} \mathbf{\%}$ & $\mathbf{T}_{\mathbf{L}}(\mathbf{k W h})$ & $\sim \mathbf{N T L}(\mathbf{k W h})$ \\
\hline Glass Factory & 665374.05 & 344057.05 & 51.70 & 32688.68 & 391368.37 \\
Old Aba Road & 642994.00 & 296078.02 & 46.05 & 15974.67 & 280103.35 \\
Rumuogba & 1131932.14 & 504509.7 & 44.57 & 35902.16 & 468607.54 \\
Rumurolu & 1076997.54 & 444691.54 & 41.29 & 38921.54 & 405770.00 \\
Rumukalagbor & 538600.17 & 220600.37 & 40.96 & 17834.71 & 202765.66 \\
Rumuibekwe & 555500.06 & 274126.84 & 49.35 & 29311.92 & 244814.92 \\
\hline
\end{tabular}

Table 6. Result of energy supplied, distribution losses, Technical losses and commercial losses (NTL) for Oct., 2017.

\begin{tabular}{llllll}
\hline Feeder & $\mathbf{E}_{\mathbf{s}}(\boldsymbol{k W h})$ & $\mathbf{E}_{\mathbf{l}}(\boldsymbol{k W h})$ & $\mathbf{E}_{\mathbf{l}} \%$ & $\mathbf{T}_{\mathbf{L}}(\boldsymbol{k W h})$ & $\sim \mathbf{N T L}(\boldsymbol{k W h})$ \\
\hline Glass Factory & 1493655.00 & 750100.24 & 50.22 & 41459.06 & 708641.18 \\
Old Aba Road & 1130762.00 & 606190.51 & 53.60 & 43429.57 & 632760.94 \\
Rumuogba & 1131932.14 & 546389.42 & 48.27 & 47223.44 & 499165.98 \\
Rumurolu & 1146671.03 & 484119.03 & 42.22 & 40024.08 & 444094.95 \\
Rumukalagbor & 580800.62 & 217844.59 & 37.51 & 26319.40 & 191525.19 \\
Rumuibekwe & 694900.70 & 362556.52 & 52.17 & 30921.53 & 331634.99 \\
\hline
\end{tabular}

Table 7. Result of energy supplied, distribution losses, Technical losses and commercial losses (NTL) for Nov., 2017.

\begin{tabular}{lllllll}
\hline Feeder & $\mathbf{E}_{\mathbf{s}}(\boldsymbol{k W h})$ & $\mathbf{E}_{\mathbf{l}}(\boldsymbol{k W h})$ & $\mathbf{E}_{\mathbf{l}}$ \% & $\mathbf{T}_{\mathbf{L}}(\boldsymbol{k W h})$ & $\sim$ NTL $(\boldsymbol{k W h})$ \\
\hline Glass Factory & 830833.99 & 343916.99 & 41.39 & 29237.08 & 484679.91 \\
Old Aba Road & 1126042.00 & 588632.7 & 52.27 & 24520.63 & 564112.07 \\
Rumuogba & 956988.23 & 421485.23 & 44.04 & 32988.12 & 388497.11 \\
Rumurolu & 1009998.5 & 408193.49 & 40.42 & 36922.19 & 371271.30 \\
Rumukalagbor & 656800.13 & 279168.28 & 42.50 & 33512.60 & 95.83 & 245655.68 \\
Rumuibekwe & 651000.39 & 262024.23 & 40.25 & 33824.51 & 228199.30 \\
\hline
\end{tabular}

Table 8. Result of energy supplied, distribution losses, Technical losses and commercial losses (NTL) for Dec., 2017.

\begin{tabular}{llllll}
\hline Feeder & $\mathbf{E}_{\mathbf{s}}(\boldsymbol{k W h})$ & $\mathbf{E}_{\boldsymbol{l}}(\boldsymbol{k W h})$ & $\mathbf{E}_{\mathbf{l}}$ \% & $\mathbf{T}_{\mathbf{L}}(\boldsymbol{k W h})$ & $\sim$ NTL $(\boldsymbol{k W h})$ \\
\hline Glass Factory & 1338953.41 & 651273.41 & 48.64 & 36905.01 & 814368.40 \\
Old Aba Road & 1287522.57 & 679388.67 & 52.77 & 48035.76 & 631352.91 \\
Rumuogba & 1329273.4 & 673172.79 & 50.64 & 36762.46 & 636410.33 \\
Rumurolu & 1712440.6 & 923417.03 & 53.92 & 32918.27 & 990498.76 \\
Rumukalagbor & 671800.11 & 397267.56 & 59.13 & 32872.33 & 364395.23 \\
Rumuibekwe & 667000.28 & 264128.98 & 39.60 & 32751.85 & 231377.85 \\
\hline
\end{tabular}


Table 9. Result of energy supplied, distribution losses, Technical losses and commercial losses (NTL) for Jan., 2018.

\begin{tabular}{llllll}
\hline Feeder & $\mathbf{E}_{\mathbf{s}}(\boldsymbol{k W h})$ & $\mathbf{E}_{\mathbf{l}}(\boldsymbol{k W h})$ & $\mathbf{E}_{\mathbf{l}}$ \% & $\mathbf{T}_{\mathbf{L}}(\boldsymbol{k W h})$ & $\sim$ NTL $(\boldsymbol{k W h})$ \\
\hline Glass Factory & 1191065.06 & 621817.36 & 52.20 & 28779.15 & 703038.21 \\
Old Aba Road & 1187159.10 & 588738.1 & 49.59 & 24243.6 & 564494.50 \\
Rumuogba & 1059144.5 & 416872.49 & 39.36 & 36122.29 & 380750.20 \\
Rumurolu & 1715471.4 & 924280.06 & 53.87 & 34220.17 & 930059.89 \\
Rumukalagbor & 562400.33 & 161139.50 & 28.65 & 34209.12 & 126930.38 \\
Rumuibekwe & 565000.05 & 146795.65 & 25.98 & 33145.05 & 113650.6 \\
\hline
\end{tabular}

Table 10. Result of energy supplied, distribution losses, Technical losses and commercial losses (NTL) for Feb., 2018.

\begin{tabular}{lllllll}
\hline Feeder & $\mathbf{E}_{\mathbf{s}}(\mathbf{k W h})$ & $\mathbf{E}_{\mathbf{l}}(\mathbf{k W h})$ & $\mathbf{E}_{\mathbf{l}} \mathbf{\%}$ & $\mathbf{T}_{\mathbf{L}}$ & $\sim \mathbf{N T L}$ \\
\hline Glass Factory & 776808.50 & 407862.5 & 52.50 & 25590.09 & 482272.41 \\
Old Aba Road & 1129968.33 & 402872.33 & 35.65 & 31806.19 & 371066.14 \\
Rumuogba & 983742.74 & 490785.74 & 49.89 & 32986.4 & 457799.34 \\
Rumurolu & 1353600.4 & 698574.44 & 51.60 & 42318.21 & 756256.23 \\
Rumukalagbor & 456800.17 & 97754.83 & 21.40 & 29361.50 & 68393.33 \\
Rumuibekwe & 501800.60 & 131798.50 & 26.27 & 32947.17 & 98851.33 & 70.00 \\
\hline
\end{tabular}

Table 11. Result of energy supplied, distribution losses, Technical losses and commercial losses (NTL) for Mar, 2018.

\begin{tabular}{llllll}
\hline Feeder & $\mathbf{E}_{\mathbf{s}}(\mathbf{k W h})$ & $\mathbf{E}_{\mathbf{l}}(\mathbf{k W h})$ & $\mathbf{E}_{\mathbf{l}} \mathbf{\%}$ & $\mathbf{T}_{\mathbf{L}}$ & $\sim$ NTL \\
\hline Glass Factory & 1128481.05 & 579048.05 & 51.31 & 35026.12 & 744021.93 \\
Old Aba Road & 1570123.39 & 707087.39 & 45.03 & 25903.14 & 681184.25 \\
Rumuogba & 1390288.65 & 715693.65 & 51.48 & 33824.21 & 681869.44 \\
Rumurolu & 1451316.91 & 964250.91 & 52.65 & 38901.01 & 925349.90 \\
Rumukalagbor & 671400.15 & 310576.63 & 46.26 & 30334.37 & 280242.26 \\
Rumuibekwe & 622500.37 & 292069.14 & 46.92 & 33926.15 & 258142.99 \\
\hline
\end{tabular}

Table 12. Result of energy supplied, distribution losses, Technical losses and commercial losses (NTL) for Apr., 2018.

\begin{tabular}{llllll}
\hline Feeder & $\mathbf{E}_{\mathbf{s}}(\mathbf{k W h})$ & $\mathbf{E}_{\mathbf{l}} \mathbf{( k W h )}$ & $\mathbf{E}_{\mathbf{l}} \mathbf{\%}$ & $\mathbf{T}_{\mathbf{L}}$ & $\sim$ NTL \\
\hline Glass Factory & 773085.47 & 405805 & 52.49 & 34972.98 & 450832.02 \\
Old Aba Road & 1347751.07 & 639619.07 & 47.46 & 26697.37 & 612921.70 \\
Rumuogba & 1208220.83 & 524977.83 & 43.45 & 35061.42 & 489916.41 \\
Rumurolu & 1356312.63 & 728240.63 & 53.69 & 36922.4 & 761318.23 \\
Rumukalagbor & 544800.71 & 206339.40 & 37.87 & 25713.73 & 180625.67 \\
Rumuibekwe & 505900.90 & 191606.64 & 37.87 & 30710.87 & 160895.77 \\
\hline
\end{tabular}

Table 13. Result of energy supplied, distribution losses, Technical losses and commercial losses (NTL) for May, 2018.

\begin{tabular}{llllll}
\hline Feeder & $\mathbf{E}_{\mathbf{s}}(\mathbf{k W h})$ & $\mathbf{E}_{\mathbf{l}}(\mathbf{k W h})$ & $\mathbf{E}_{\mathbf{l}} \mathbf{\%}$ & $\mathbf{T}_{\mathbf{L}}$ & $\sim \mathbf{N T L}$ \\
\hline Glass Factory & 1027890.00 & 526775.88 & 51.24 & 41318.46 & 585457.42 \\
Old Aba Road & 1981349.41 & 1045587.4 & 52.77 & 35937.97 & 1109649.44 \\
Rumuogba & 1214563.48 & 570154.48 & 46.94 & 34827.18 & 535327.30 \\
Rumurolu & 1291824.98 & 695876.92 & 53.86 & 34208.49 & 761668.43 \\
Rumukalagbor & 628800.26 & 279732.17 & 44.49 & 31511.49 & 248220.68 \\
Rumuibekwe & 620700.80 & 286108.39 & 46.09 & 34782.62 & 251325.77 \\
\hline
\end{tabular}

Table 14. Result of energy supplied, distribution losses, Technical losses and commercial losses (NTL) for Jun., 2018.

\begin{tabular}{llllll}
\hline Feeder & $\mathbf{E}_{\mathbf{s}}(\mathbf{k W h})$ & $\mathbf{E}_{\mathbf{l}}(\boldsymbol{k W h})$ & $\mathbf{E}_{\mathbf{l}} \mathbf{\%}$ & $\mathbf{T}_{\mathbf{L}}(\boldsymbol{k W h})$ & $\sim$ NTL $(\boldsymbol{k W h})$ \\
\hline Glass Factory & 713266.26 & 297520 & 41.71 & 38934.27 & 358585.73 \\
Old Aba Road & 1634732.47 & 873381.47 & 53.42 & 35350.22 & 938031.25 \\
Rumuogba & 1002087.94 & 411129.91 & 41.03 & 33276.11 & 377853.80 \\
Rumurolu & 1065833.33 & 570467.33 & 53.52 & 31277.15 & 649190.18 \\
Rumukalagbor & 628800.12 & 306892.74 & 48.81 & 33273.15 & 273619.59 \\
Rumuibekwe & 620700.00 & 292756.48 & 47.17 & 32472.80 & 260283.68 \\
\hline
\end{tabular}

\subsection{Annual Revenue Technical and Commercial Losses}

The result of sum of all the monthly technical and commercial losses and its equivalent revenue based on the tariff (\#30.82) are given below. 
Table 15. Table of Annual Revenue Technical and Commercial losses.

\begin{tabular}{lllll}
\hline Feeder & $\begin{array}{l}\text { Annual Technical } \\
\text { loss }(\boldsymbol{k W h})\end{array}$ & $\begin{array}{l}\text { Annual Commercial } \\
\text { loss }(\boldsymbol{k W h})\end{array}$ & $\begin{array}{l}\text { Annual Revenue } \\
\text { Technical. loss (\#) }\end{array}$ & $\begin{array}{l}\text { Annual Revenue Commercial } \\
\text { loss (\#) }\end{array}$ \\
\hline Glass Factory $(k W h)$ & 423347.96 & 6634805.34 & $13,047,584.13$ & $204,484,700.6$ \\
Old Aba Road $(k W h)$ & 346528.17 & 6946517.28 & $10,679,998.20$ & $214,091,662.6$ \\
Rumuogba $(k W h)$ & 430840.60 & 6075225.55 & $13,278,507.29$ & $187,238,451.5$ \\
Rumurolu $(k W h)$ & 439774.51 & 8790080.51 & $13,553,850.40$ & $270,910,281.3$ \\
Rumukalagbor & 368165.69 & 2294378.56 & $11,346,866.57$ & $70,712,747.22$ \\
Rumuibekwe & 392707.55 & 2732906.74 & $12,103,246.69$ & $84,228,185.73$ \\
Net Annual Revenue Technical and Commercial losses $1,082,225,968.88 \mathrm{k}$ & $74,010,053.28$ & $1,031,666,028.86$ \\
\hline
\end{tabular}

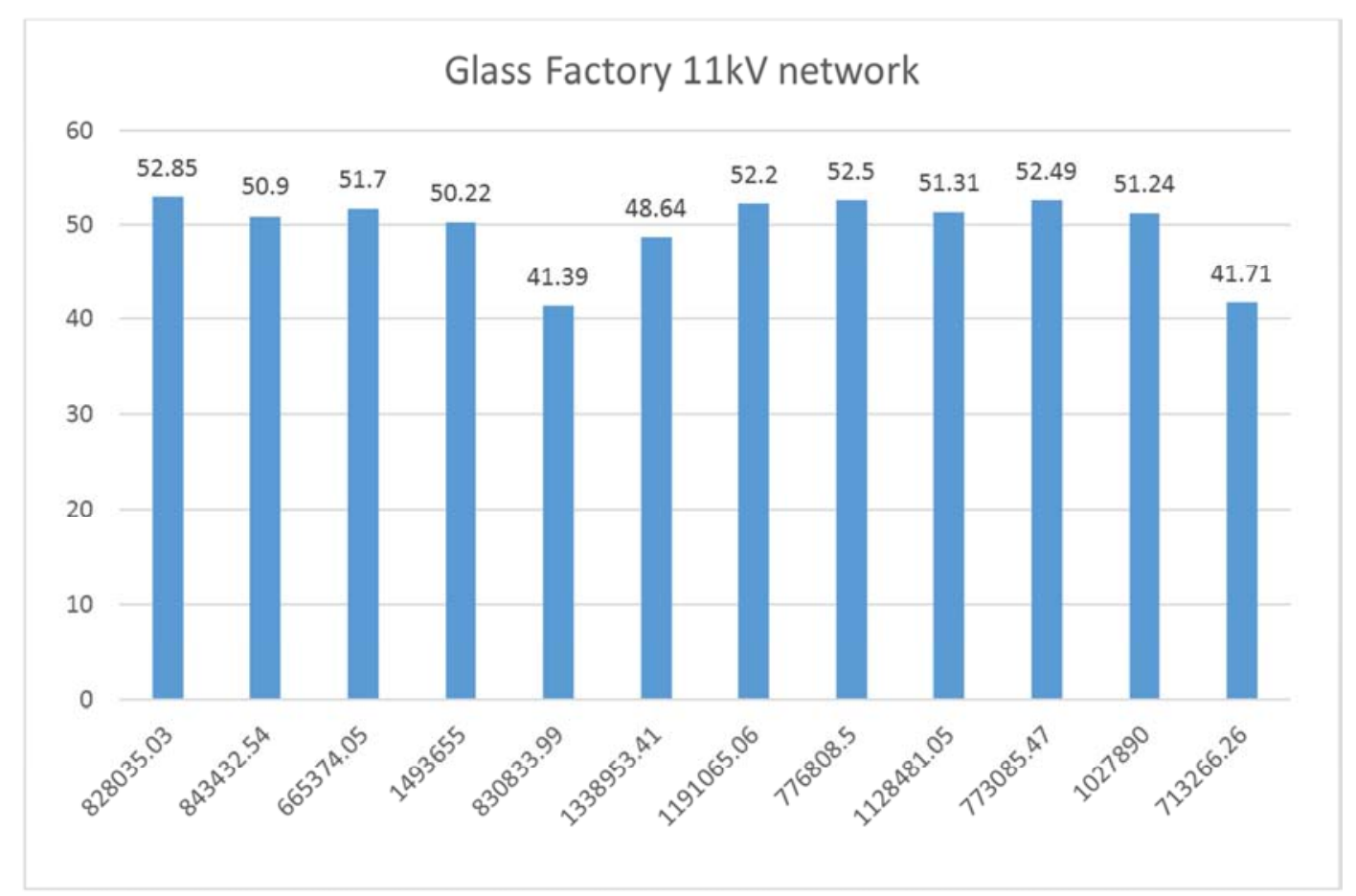

Figure 1. Bar chart showing distribution losses $E_{l} \%$ versus energy supplied $E_{S}$ on Glass Factory network.

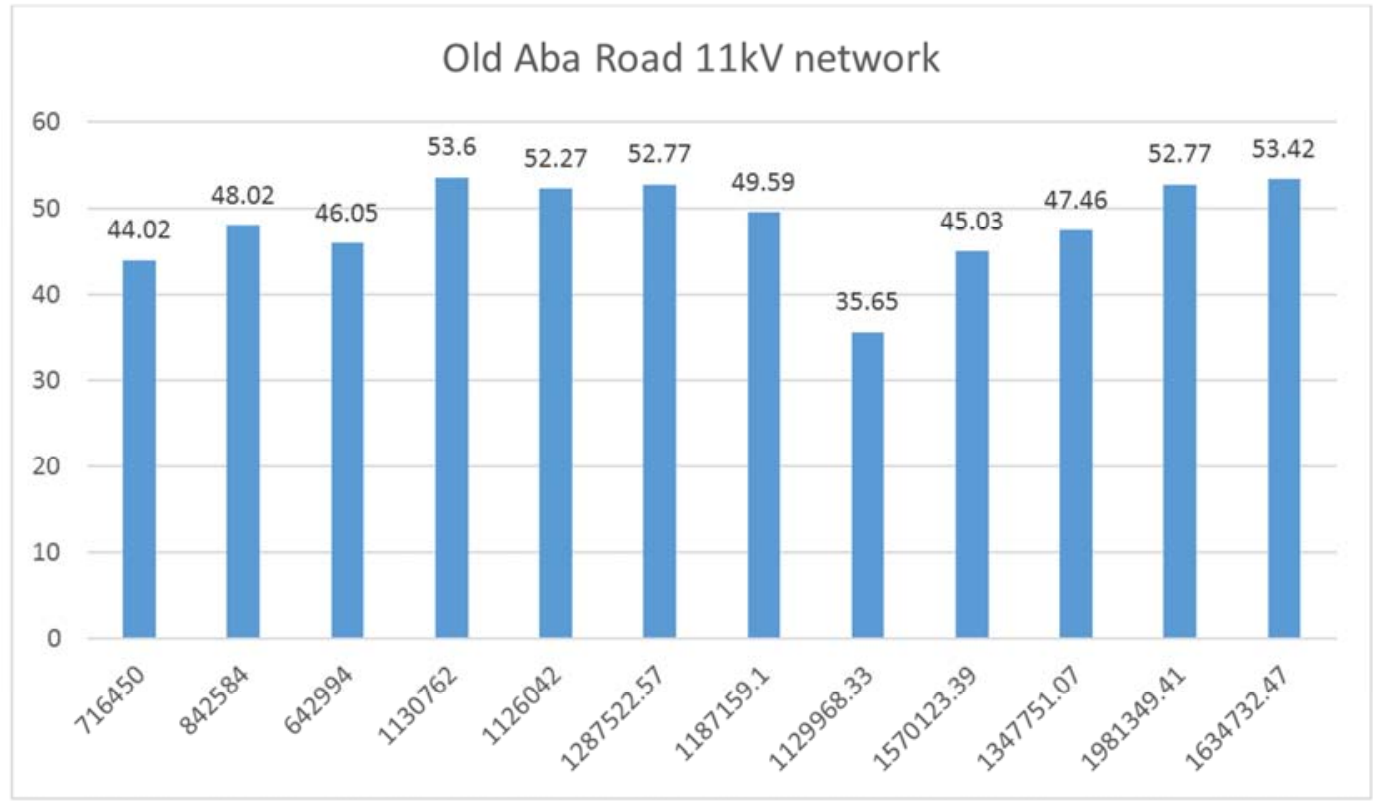

Figure 2. Bar chart showing distribution losses $E_{l} \%$ versus energy supplied $E_{s}$ on Old Aba Road feeder. 


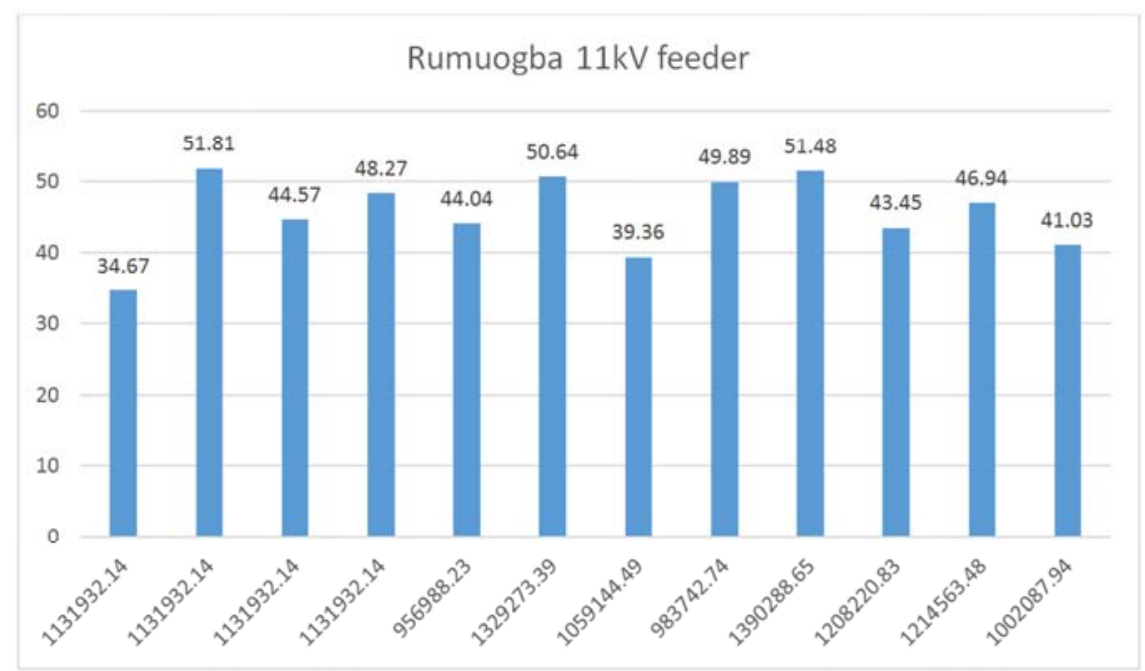

Figure 3. Representing bar chart of distribution losses $E_{l} \%$ versus energy supplied $E_{s}$ on Rumuogba feeder.

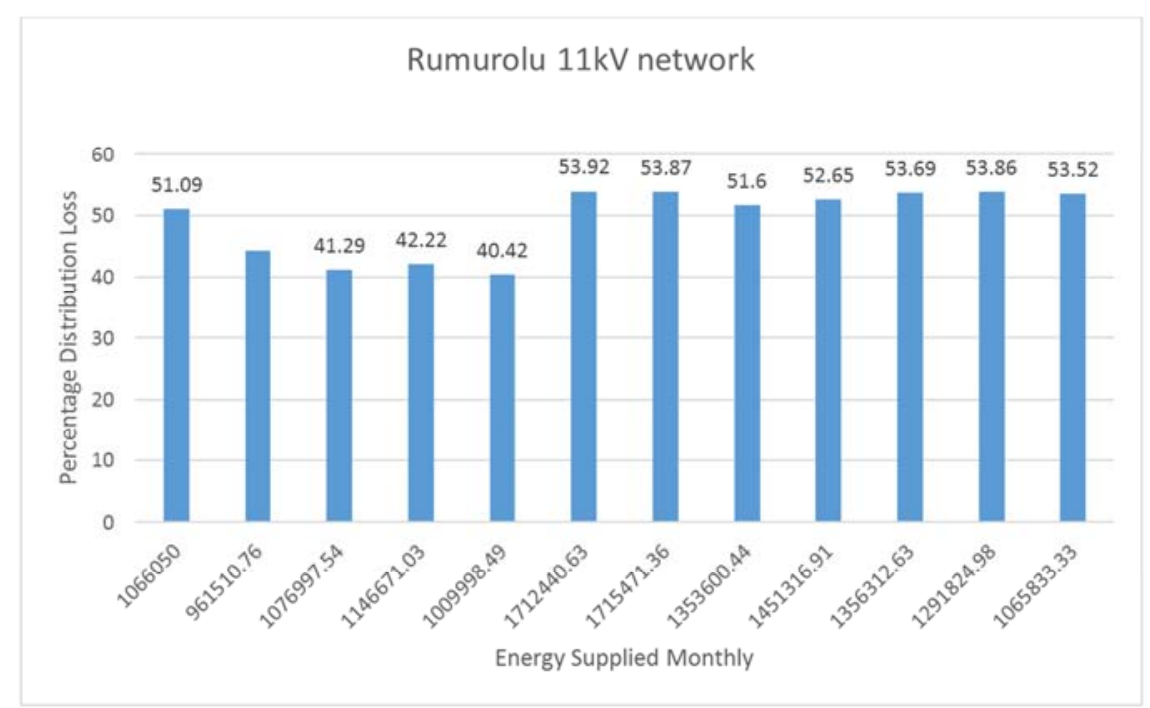

Figure 4. Representing bar chart of distribution losses $E_{l} \%$ versus energy supplied $E_{s}$ on Rumurolu feeder.

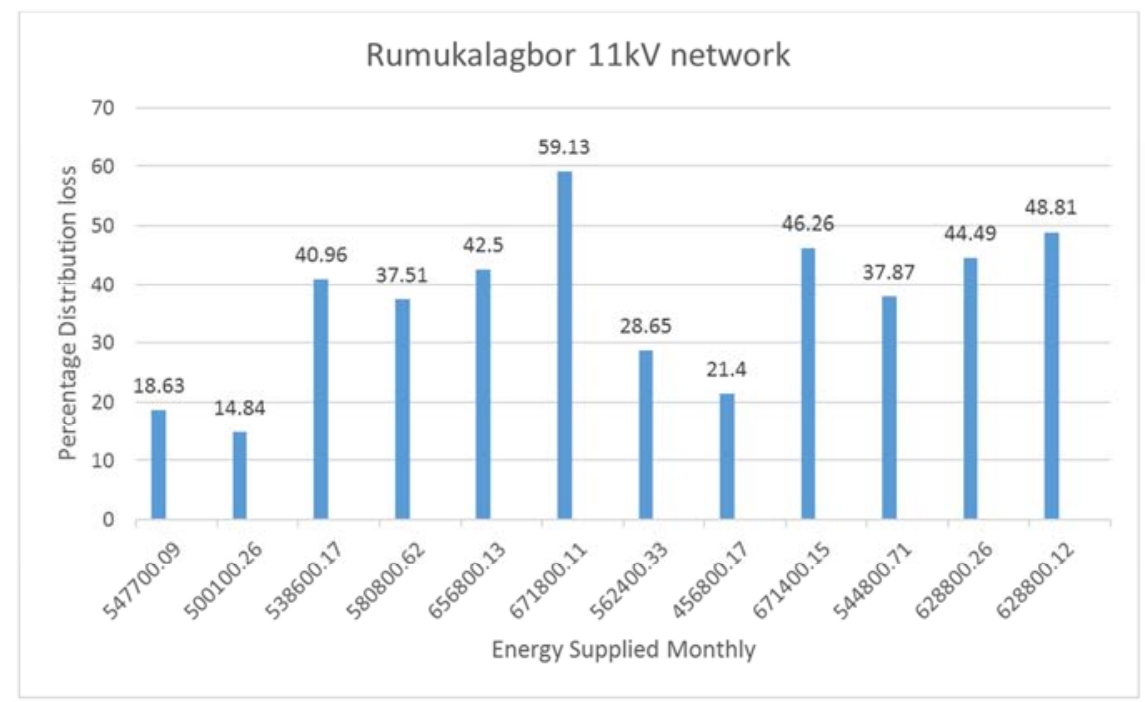

Figure 5. Representing bar chart of distribution losses $E_{l} \%$ versus energy supplied $E_{s}$ on Rumukalagbor $11 \mathrm{kV}$ feeder. 


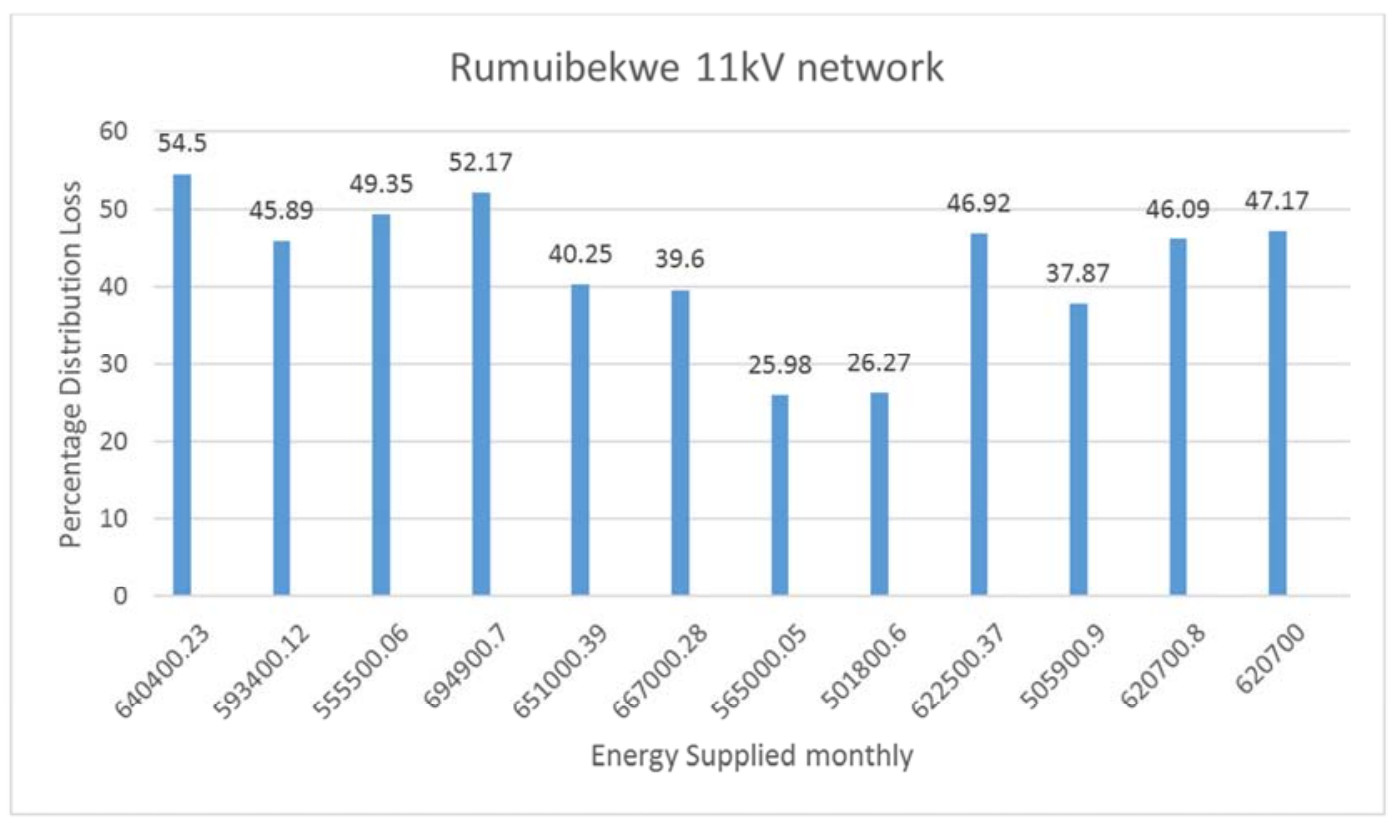

Figure 6. Representing bar chart of distribution losses $E_{l} \%$ versus energy supplied $E_{s}$ on Rumuibekwe $11 \mathrm{kV}$ feeder.

\subsection{Data Analysis}

The percentage distribution losses of the six (6) feeders are high but that of Glass Factory feeder is always very high every month as a result of much faults on the network. For the period of one year, the percentage loss of the nontechnical loss are also very high. From the evaluation table, the annual technical revenue losses on each feeders; Glass Factory, Old Aba Road, Rumuogba, Rumurolu, Rumukalagbor and Rumuibekwe are \#13,047,584.13k, \#10,679,998.20k,\#13,278,507.29k,\#13,553,850.40k, $\# 11,346,866.57 k$, and \#12,103,246.69k respectively, which amounted to \#74,010,053.28 $\mathrm{k}$ as the net annual technical revenue losses of the six feeders. From the result, it is observed that the distribution loss ranges between $14-54 \%$ of the total energy billed from the energy supplied. The annual commercial revenue losses on each feeders; Glass Factory, Old Aba Road, Rumuogba, Rumurolu, Rumukalagbor and Rumuibekwe are \#204,484,700.6k , \#214,091,662.6k, \#187,238,451.5 k, \#270,910,281., \#70,712,747.22 k and $\# 84,228,185.73 k$ respectively. These summed up to \#876,725,095.92 as the net annual non-technical loss of the six feeders. From the table, the annual non-technical (commercial) revenue loss on the feeders are higher than the annual technical revenue loss. This means that the nontechnical loss has a very much considerable percentage of losses incurred from the distribution network. From these analysis, the power distribution company loose about \#1,082,225,968.88k (Over one billion naira loss per year) on the technical and non-technical loss of the six $11 \mathrm{kV}$ network annually and these contributed to the major challenges faced by the power distribution companies.

From the chart of distribution loss against energy supplied, it is observed that the percentage distribution losses increase more in the month of July, 2017 and February, 2018 on the
Glass Factory $11 \mathrm{kV}$ feeder, October, 2017 and June 2018 on the Old Aba Road 11kV network, August 2017 and March, 2018 on Rumuogba $11 k V$ network, December 2017, January 2018, April 2018 and May 2018 on Rumurolu $11 \mathrm{kV}$ network, Dec. 2017 and June 2017 on Rumukalagbor $11 \mathrm{kV}$ feeder and July 2017 and Oct. 2017on Rumuibekwe $11 \mathrm{kV}$ network.

\section{Summary, Conclusions, Contributions and Recommendations}

\subsection{Summary}

The technical and commercial losses on Glass Factory $11 \mathrm{kV}$ feeder, Old Aba Road, Rumuogba, Rumurolu, Rumukalagbor and Rumuibekwe $11 \mathrm{kV}$ networks have been evaluated to know the amount of revenue lost between July 2017 to June 2018. The results achieved on the evaluation of these losses help to know how to reduce the rate of losses on the power distribution network.

\subsection{Conclusions}

Having completed the twelve months (1 year) evaluation of technical and non-technical losses carried out on the $11 \mathrm{kV}$ distribution feeders which radiated from $2 X 15 M V A, 33 / 11 k V$ Akani injection substation of Port Harcourt distribution network, it is observed that the evaluated technical loss between 2017-2018 (period of one year) gave 6634805.34kWh $(\# 204,484,700.6)$ for Glass factory network, 6946517.28kWh $(\# 214,091,662.60)$ for Old Aba Road feeder, 6075225.55kWh (\#187,238,451.50) for Rumuogba feeder, $8790080.51 \mathrm{kWh}(\# 270,910,281.3)$ for Rumurolu network, $368165.69 \mathrm{kWh}(\# 11,346,866.57)$ for Rumukalagbor and $392707.55 \mathrm{kWh}(\# 12,103,246.69)$ for Rumuibekwe while that of non-technical loss amounted to $423347.96 \mathrm{kWh}$ 
(\#13,047,584.13) for Glass factory network, 346528.17kWh (\#10,679998.20) for Old Aba Road feeder, 430840.60kWh (\#13,278,507.29) for Rumuogba, 439774.51kWh (\#13,553,850.40) for Rumurolu network, 2294378.56kWh $(\# 70,712,747.22)$ for Rumukalagbor and 2732906.74kWh (\#84,228,185.73) for Rumuibekwe. Several methods have been used to evaluate power losses but statistical evaluation method can be used to obtain reliable results. These power losses are caused as a result of bypassing the meter, tampering or adjusting the meter to run slow or get burnt, wrong meter reading and wrong billing, manipulating of recorded data, illegal connection of new customer without proper capturing thereby overloading the transformer and reducing its efficiency, closing of existing accounts (bills), non-payment of bills, aged network feeders, delay in carrying out disconnection on defaulters, hanging of wires in the night (J-hook), which bridges the line and caused explosion on the transformer. All these energy losses cannot be stopped or minimize if drastic measures are not taken.

\subsection{Recommendations}

Project on network re-conductoring of the aged power distribution lines should be carried out to reduce tripping and much loss of energy. Maintenance and replacement of aged electrical equipment. Private investors with the support of federal government should create revenue protection departments (RPD) and security agencies to check energy theft, meter bypass (prepaid and post-paid) and they should also attach penalty to the defaulters. Treating of 'hotspots' on the lines, cables and the equipment and also loading the feeders to the capacity they can carry (in $M W$ ). In recommendation, community engagement and enlightenment on the implication of hanging wires and non-payment of bills should be carried out. Frequent checking on the illegal hanging of electric wires should be done to avoid bridging of the lines which affect the transformers. Taking of load reading of the transformers to know their percentage loading and carry out load balancing of the network on the overloaded transformers. These will also contribute to the reduction of losses on power distribution networks.

\subsection{Contributions to Knowledge}

In order to evaluate and minimizes these energy losses from the distribution source to the consumer end, installation of automated distribution system which monitors the load flow will help in controlling the technical and non-technical losses in the distribution lines. These will have an effective and reliable power distribution supply in the system and thereby reduce complaints on constant power failure. Private investors with the support of government (Nigeria electricity regulatory commission) should make prepaid meters available to all electric power users in order to reduce over estimated bills or under estimated bills which affects the power industry. Consumers should be educated or sensitized on how to manage the power received rather than leaving outside bulbs on during the day and other electrical appliances on for nothing.

\section{References}

[1] Adesina, L. M. \& Ademola A. (2016), 'Determination of Power System Losses in Nigeria Electricity Distribution Networks' P1-6. International Journal of Engineering and Technology Volume 6 No. 9 Sept., 2016.

[2] Adewale, A. (2014) “A Guide to the Power Sector." pp. 2-4.

[3] Alumona. T. L, Nwosu Moses. O, Ezechukwu A. O, Chijioke Jonah (2014), 'Overview of Losses and Solution in Power Transmission Lines'. p1-8, ISSN 2224-610x (Paper) ISSN 2221-0603 (online) Vol. 4, No. 8, 2014.

[4] Anumaka M. C. (August, 2012) “Analysis of Technical Losses in Electrical Power System (Nigerian 330kV Network as A Case Study)". p. 1-2.

[5] Ayanruoh F., (26, February, 2013) "Challenges facing the Nigerian Power Sector". p. 2-3.

[6] Hachimenum N. Amadi, Ephraim N. C. Okafor, Fabian I. Izuegbunam. (2016), 'Assessment of Energy Losses and Cost Implications in the Nigerian Distribution Network' American Journal of Electrical and Electronic Engineering, 2016, Vol. 4, No. 5, 123-130. doi: 10.12691/ajeee-4-5-1.

[7] Hachimenum N. Amadi, Fabian I. Izuegbunam and Ephraim N. C. Okafor. (2016),'Evaluation Of Losses In Distribution Networks of Selected Industrial Cities In Nigeria Using ETAP'. Pp. 1-12, British Journal of Applied Science \& Technology, 17 (6): XX-XX, 2016. Article no. BJAST. 29910, ISSN: 2231-0843, NLM ID: 101664541.

[8] Iderjeet S. S. \& Maninder (2013), 'Analysis of Losses in Power System and Its Economic Consequences in Power Sector'. International Journal of Enhanced Research in Science Technology and Engineering, ISSN: 2319-7463, Vol. 2 Issue 7, July-2013, pp. (90-98), www.erpublications.com.

[9] Khalil Y. A (2019), 'Power System Losses Evaluation and Estimation'. P17, 22. 'National Power Training Institute of Nigeria'.

[10] Kulkarni V. A. \& Katti P. K (2011), 'Estimation of Distribution Transformer Losses in Feeder Circuit' International Journal of Computer and Electrical Engineering, Vol. 3, No. 5, October 2011. Pp. 659-662.

[11] Marwan M. M. \& Imad H. I. (2002), 'Power Losses Reduction in Low Voltage Distribution Networks By Improving the Power Factor in Residential Sector'. Pakistan Journal of Applied Sciences 2 (7): 727-732, 2002.

[12] Mendoza J. E., Lopez. M, Fingerhuth. S, Carvajal. F, Zuniga. G. (2013), 'Comparative Study of Methods for Estimating Technical Losses in Distribution Systems with Distributed Generation'. Int J Comput Commun, ISSN 1841-9836, 8 (3): 444-459 June, 2003.

[13] Mufutau. W. O, Jokojeje. R. A, Idowu. O. A., Sodunke. M. A. (2015), 'Technical Power Losses Determination: Abeokuta, Ogun State, Nigeria Distribution Network as a Case Study'. IOSR Journal of Electrical and Electronics Engineering (IOSR-JEEE), E-ISSN: 2278-1676, P-ISSN: 2320-3331, Volume 10, Issue 6 Ver. 1 (Nov. - Dec. 2015) Pp. 01-10. 
[14] Narong M., Nittaya G., Tanes T., Sumchai A., Weerachai C. \& Toshifumi Y. (2009), 'Analysis of Technical Loss in Distribution Line System' Pp. 26-30. narong_kmutt@hotmail.com.

[15] Naveen K., (1999),'AT\&C Losses in Power Distribution'. Pp. 1-27, Feedback Ventures Private Limited, India.

[16] Navani J. P., Sharma N. K \& Sonal S. (2017), ‘Technical and Non-Technical Losses in Power System and Its Economy Consequence in Indian Economy’. Pp. 757-761. International Journal of Electronics and Computer Science Engineering, ISSN: 2277- 1956, V1N2-757-761. www.ijecse.org.

[17] Navani. J. P, Sharma. N. K \& Sonal Sapra (2012), 'A Case Study of Analysis of Technical and Non-Technical Losses in Power System and Its Impact on Power Sector'. International Journal of Advances in Engineering Science and Technologies, ISSN 2319-1120, pp. 137-140, www.sestindia.org/volumeijaest/ and www.ijaestonline.com.

[18] Newspaper. (March, 2013) "Power Holding Company of Nigeria" Newspaper pp. 1-3.

[19] Nwohu M. N., Mohammed. A. S, Usman A. D. (2017), 'Methodology for Evaluation of Aggregate Technical, Commercial and Collection (ATC\&C) Losses in a Typical Radial Distribution System'. International Journal of Research Studies in Electrical and Electronic Engineering (IJRSEEE), Volume 3 Issue 2, 2017, pp. 1-10, ISSN: 2454-9436 (Online), www.arcjournals.org.

[20] Oda R., Qais A., \& Mohammed A. (2015), 'Evaluation of Electric Energy Losses in Southern Governorate of Jordan Distribution Electric System'. International Journal of Energy Engineering 2015, 5 (2): 25-33. DOI: 10.5923/j.ijee.20150502.02. Pp. 25-33.
[21] Okereafor. F. C, Idoniboyeobu D. C., Bala T. K (2017), 'Analysis of 33/11kv RSU Injection Substation for Improved Performance with Distribution Generation (DG) Units'. American Journal of Engineering Research (AJER), E-ISSN: 2320-0847, P-ISSN: 2320-0936, Volume-6, Issue-9, Pp. 301316.

[22] Oliveira C. C. B., Kagan. N., Meffe. A., Jonathan. S., Caparvoz. S., Cavaretti. J. L. (2015), 'A New Method for the Computation of Technical Losses in Electrical Power Distribution Systems'p1-3.

[23] Sailaja G., Saisesha. M. \& Ayyaroa. T. S. L. V. (2013), 'A Statistical Analysis of Loss Factor: A Case Study in APEPDCC-KAKINADA' P1-3. G. Sailaja et al. / International Journal of Engineering Science and Technology (IJEST).

[24] Sameer S. M., Mohammed H. Y. \& Hussein H. A. (2011), 'Evaluation of Energy Losses in Kirkuk Distribution Electric System Area'. Pp. 144-150, Iraq J. Electrical and Electronic Engineering, Vol. 7 No. 2, 2011.

[25] Sanusi, G. (2007) "Nigeria Electricity Regulatory Commission." www.nercng.org.

[26] Seethalekshmi K., Trivedi. U. C \& Ramamoorty. M. (2002), 'Technical Loss Evaluation in Distribution Feeders' Pp. 673674. Indian Institute of Technology, Kharagpur 721302 December 27-29, 2002.

[27] Uwaifo S. O., (June, 2018) "Conversation in Electric Utility Engineering”. P. 9.

[28] Working Group of Loss Reduction (2017), 'Reduction of Technical and Non-Technical Losses in Distribution Networks' CIRED WG CC- 2015-2, Pp. 18-21. 